\title{
Multiplikasi Input Analog pada PLC menggunakan Multiplekser IC74HC4067
}

\section{ASEP ANDANG, RENDI PRIYATNA, FIRMANSYAH MAULANA SUGIARTANA NURSUWARS}

\author{
Jurusan Teknik Elektro, Universitas Siliwangi, Tasikmalaya, Indonesia \\ email: andhangs@unsil.ac.id
}

Received 30 Maret 2021 | Revised 29 April 2021 | Accepted 10 Juni 2021

\begin{abstract}
ABSTRAK
Kebutuhan sistem otomasi untuk pekerjaan tentu sangat dituntut untuk menjadi lebih efektif dan efisien seperti halnya pemanfaatan PLC dalam bidang industri untuk menjalankan segala aktifitas menjadi otomatis, terkadang sistem ADC (analog to digital converter) pada PLC itu terbatas, dan harus diberi tambahan ekstensi eksternal yang dijual terpisah di masing-masing vendor. Tentunya harganya juga terkadang lebih mahal dari pada Unit pemrosesnya, hal ini yang sering menjadi sebuah pertimbangan. Contoh nya sistem ADC pada PLC CP1L-E memiliki 2 kanal. Oleh karena itu penelitian ini dilakukan, dengan melakukan perancangan multiplekser dan demultiplekser analog dengan memanfaatkan IC 74HC4067, hasil dari penelitian ini dalam 1 kanal input analog PLC CP1L-E dapat menjadi 16 kanal input dengan waktu pensaklaran direkomendasikan diatas 0,1detik / kanal berdasarkan hasil selisih pembacaan nilai ADC dibandingkan dengan tanpa melalui multiplekser berkisar antara 0,00\% sampai 1,969\%, dan multiplekser ini direkomendasikan untuk penggunaan sinyal input pada tegangan O sampai 5 volt.
\end{abstract}

Kata kunci: ADC, Multiplekser,Demultiplekser, IC CD74HC4067, PLC

\begin{abstract}
The need for automation systems for work is certainly highly demanded to be more effective and efficient as well as the use of PLCS in the industrial sector to carry out all activities automatically, sometimes the ADC (analog to digital converter) system on the PLC is limited, and must be given additional external extensions that are sold separately for each vendor. Of course the price is also sometimes more expensive than the processing unit, this is often a consideration. For example, the ADC system on the CP1L-E PLC has 2 channels. Therefore, this research was carried out, by designing an analog multiplexer and demultiplexer using IC 74HC4067, the results of this study in 1 analog input channel PLC CP1L-E can be 16 input channels with recommended switching times above 0.1 seconds / channel based on the results of the difference. The reading of the ADC value compared to without going through the multiplexer ranges from $0.00 \%$ to $1.969 \%$, and this multiplexer is recommended for the use of input signals at a voltage of 0 to 5 volts.
\end{abstract}

Keywords: ADC, Multiplexer, Demultiplexer, IC CD74HC4067, PLC 
Andang, dkk

\section{PENDAHULUAN}

Dunia digitalisasi pada zaman modern seperti saat ini menjadi sebuah tuntutan untuk menjadikan pekerjaan lebih efektif dan efisien, namun secara alamiah bentuk sinyal di dunia ini sebagian bersifat analog, teknologi-teknologi yang ada saat ini pada dasarnya memanfaatkan sinyal-sinyal analog yang dibaca dan dimanfaatkan sehingga menjadi sebuah informasi dalam bentuk digital (Ahmad, 2012).

ADC (Analog to Digital Converter) adalah konverter yang menangani perubahan-perubahan sinyal yang dibaca secara analog kemudian diubah menjadi data digital seperti pembacaan sensor suhu, tegangan, suara, cahaya, dan lainnya (Sagita, Khotijah, \& Amalia, 2013).

Penggunaan ADC ini dimanfaatkan salah satunya dalam pencacahan suhu dengan menggunakan parameter arus (Nugroho, dkk, 2017) aplikasi pada seven segment (Sarjana, 2019) dan timbangan (Rachmat, dkk, 2016) juga pada PLC (Programable Logic Controller) (Anton, dkk, 2015)(Rizaldi, dkk, 2015).

Pada perkembangannya tidak semua jenis PLC memiliki port analog tergantung dari seri dan jenis yang dikeluarkan oleh masing-masing produsen (Petruzella, 2017), kalaupun mempunyai modul analog umumnya terbatas, hal tersebut menjadi sebuah kendala dalam membuat sistem monitoring dan kendali dalam industri, adapun modul tambahan untuk membuat kanal pada analog PLC lebih banyak, namun modul tersebut terkadang lebih mahal dari unit prosesnya.

Salah satu metode untuk memperbanyak akses input analog pada PLC adalah dengan penggunaan multiplekser dan demultiplekser. Multipleksing merupakan teknik penggabungan dari beberapa sinyal untuk dikirimkan secara bersamaan pada suatu kanal transmisi. Perangkat yang melakukan hal tersebut disebut multiplekser. Sedangkan gabungan sinyal-sinyal tersebut kemudian akan dipisahkan kembali sesuai dengan kanalnya, proses pemisahan tersebut disebut dengan demultipleksing, reciever atau perangkat yang melakukan demultipleksing disebut dengan demultiplekser (Mukherjee, 2020).

Metode ini diimplementasikan dalam memperbanyak input analog pada berbagai mikrokontroller seperti: NodeMCU ES8266(Julsam, dkk, 2019), ARM Cortex-M3 (You, dkk, 2018), PIC18F6585 (Rangarajan,dkk,2008), Atmega328 (Wisitwekin,dkk, 2017)(Gong, dkk, 2014) dan arduino (Weber, dkk, 2016).

Dalam artikel ini akan di bahas bagaimana melakukan multiplikasi kanal analog input pada PLC CP1L-E menggunakan metode multiplekser dengan IC 74HC4067, serta dibahas waktu pensaklaran yang sesuai sehingga di dapatkan hasil error pembacaan input analog yang paling kecil.

\section{METODE}

Multiplekser merupakan rangkaian logika kombinasional yang berfungsi untuk meneruskan data dengan pemilihan data masukan baik $\mathrm{I}_{0}, \mathrm{I}_{1}, \mathrm{I}_{2}$ maupun $\mathrm{I}_{3}$ berdasarkan sinyal kendali $\mathrm{S}_{0}$ dan $S_{1}$, data ini akan diteruskan oleh keluaran $Y$. demikian pula cara kerja demultipekser merubah masukan data di I dengan kendali $S_{0}$ dan $S_{1}$ menjadi keluaran $Y_{0}$ sampai $Y_{3}$ seperti pada Gambar 1. 


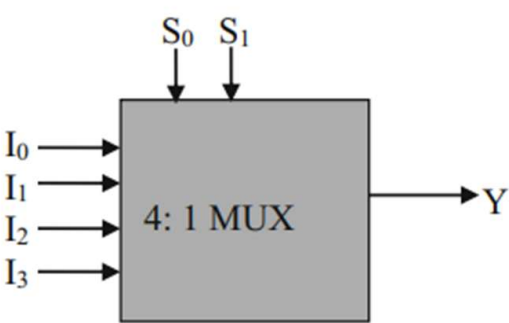

(a)

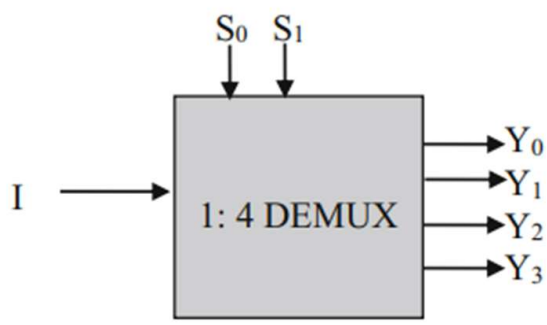

(b)

Gambar 1.(a) Multiplekser (b) Demultiplekser

Mengingat kebutuhan untuk mengindra sinyal analog yang akan ditampilkan dalam format digital baik berupa display ataupun input proses PLC, maka sinyal analog tersebut diubah menjadi digital dengan menggunakan ADC. Proses ini dilakukan dengan metode Multipleksing yaitu metode menggabungkan beberapa sinyal analog atau digital menjadi satu sinyal analog atau digital (Hidayat, 2015).

Perancangan multipikasi input sinyal analog ini terbagi menjadi perancangan Hardware yang berupa perakitan IC multiplekser 74HC4067, pengkawatan dengan PLC dan menghubungkannya dengan catu daya dan perancangan software berupa pembuatan bahasa ladder pada PLC untuk dapat menampung aliran data yang datang dari IC multiplekser yang disimpan dalam memori PLC.

\subsection{Perancangan Hardware}

Perancangan hardware multiplikasi input analog pada PLC dituangkan dalam bentuk flowchart sistem, arsitektur sistem dan spesifikasi hardware yang digunakannya seperti pada Gambar 2.

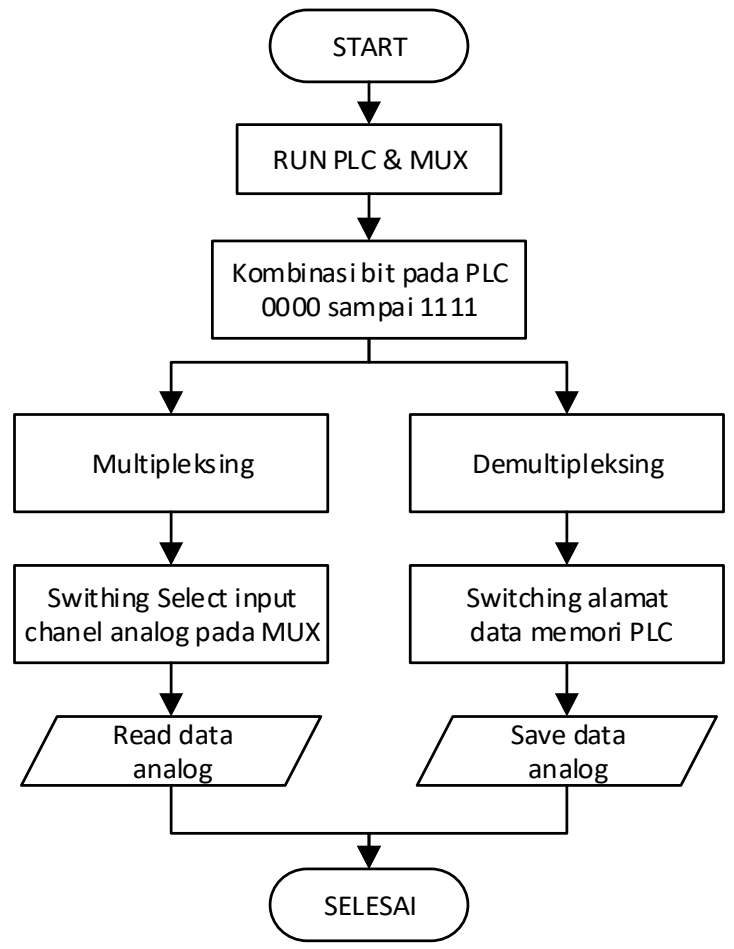

Gambar 2. Flowchart Sistem 
Cara kerja multiplekser dijelaskan dalam flowchart sistem seperti pada Gambar 2, multiplekser ini bekerja berdasarkan kombinasi biner yang dihasilkan dari pin Out digital PLC, dengan clock yang disesuaikan, kombinasi biner yang dihasilkan oleh PLC mulai dari 0000 sampai 1111 mengsaklarkan kanal pada multiplekser untuk membaca data-data analog Input yang terhubung pada 16 kanal multplekser, selanjutnya pada waktu yang bersamaan kombinasi biner tersebut mengalokasikan data memori yang dipilih pada PLC untuk penyimpanan data pada masing-masing kanal analog.

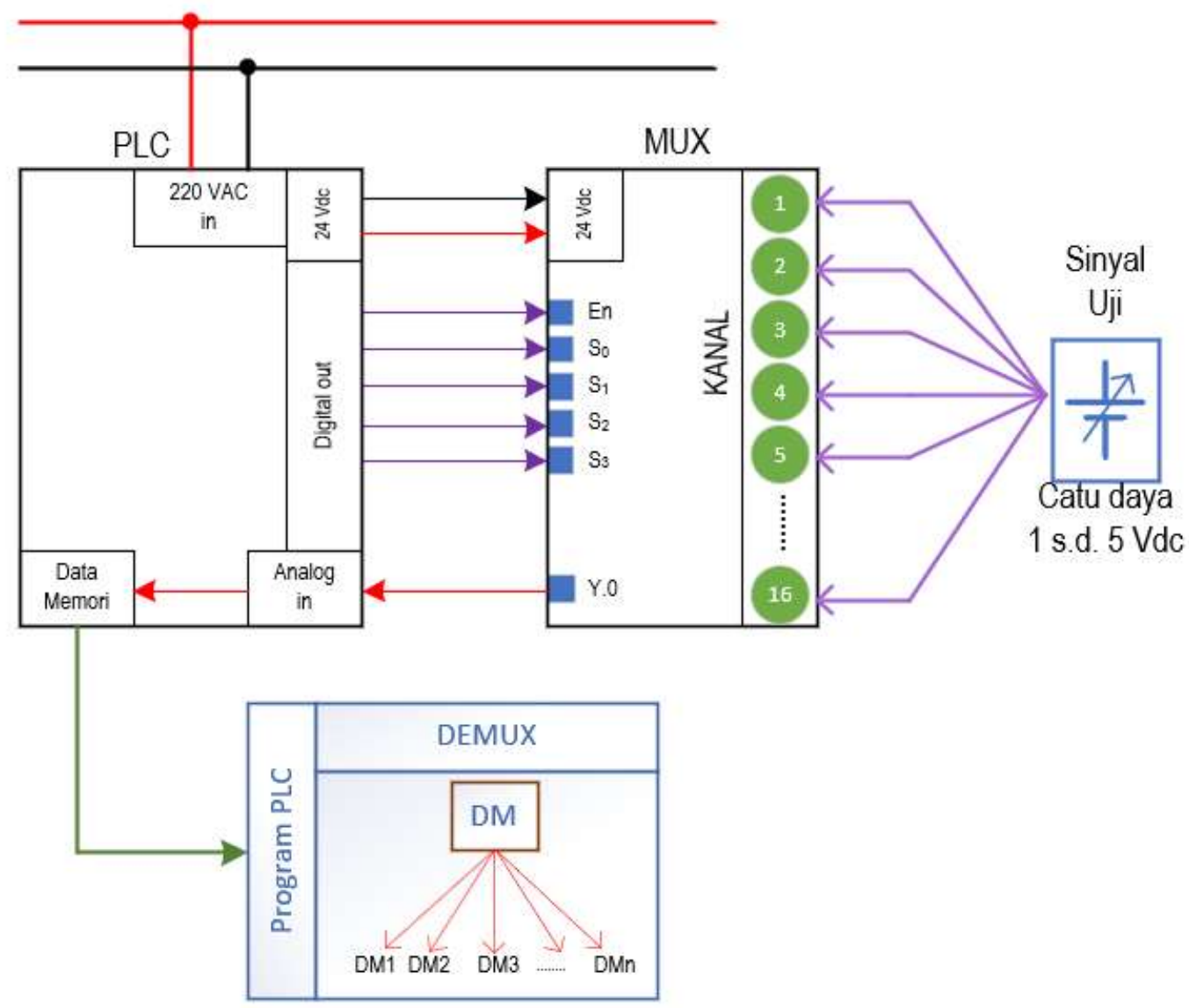

Gambar 3. Arsitektur Sistem

Arsitektur sistem terbagi menjadi 2 bagian seperti pada Gambar 3. Dimulai dengan membaca banyak input sampai 16 kanal menjadi satu keluaran data (Multiplekser), dan dari satu data keluaran data analog tersebut menjadi satu inputan analog ke PLC, kemudian data dari data analog tersebut dipisahkan lagi berdasarkan nilai pembacaan awalnya (Demultiplekser) di bagian program PLC untuk di simpan di DM (Data Memori). Untuk kerja sistem multiplekser dan demultiplekser dijelaskan pada flow chart sistem pada Gambar 2. Pada tahap perancangan hardware dilakukan juga pemilihan spesifikasi parameter untuk komponen lainnya. Pemilihan spesifikasi didasarkan pada kebutuhan sistem yang akan dibuat seperti:

\section{a. Multiplekser}

Multiplekser yang digunakan yaitu IC 74CH4067, IC multiplekser ini merupakan sejenis saklar analog yang dikontrol secara digital. IC ini dapat berfungsi sebagai multiplekser atau demultiplekser tergantung kebutuhan penggunaannya, untuk bentuk dan keterangan masingmasing pin seperti pada Gambar 4. 


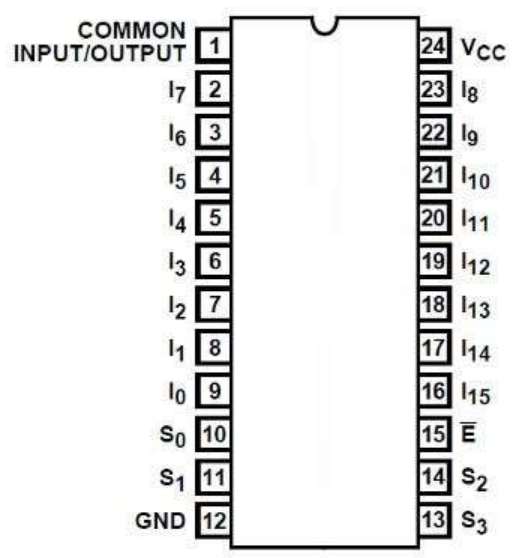

Gambar 4. Pin Konfigurasi 74HC4067

Keterangan dari masing-masing pin dan fungsional pin pada IC $74 \mathrm{CH} 4067$ dijelaskan pada Tabel 1

Tabel 1. Deskripsi Pin IC 74HC4067
\begin{tabular}{|l|l|l|}
\hline Simbol & Pin & Deskripsi \\
\hline Vee & 24 & Suply voltage \\
\hline GND & 12 & Ground suply \\
\hline E & 15 & Enable input \\
\hline COM input / output & 1 & \\
\hline $\mathrm{I}_{0}, \mathrm{I}_{1}, \mathrm{I}_{2}, \mathrm{I}_{3}, \mathrm{I}_{4}, \mathrm{I}_{5}, \mathrm{I}_{6}, \mathrm{I}_{7}, \mathrm{I}_{8}, \mathrm{I}_{9}, \mathrm{I}_{10}, \mathrm{I}_{11}, \mathrm{I}_{12}$, & $9,8,7,6,5,4,3,2,23,22,21,20,19,1$ & Independent \\
$\mathrm{I}_{13}, \mathrm{I}_{14}, \mathrm{I}_{15}$. & $8,17,16$ & input/output \\
\hline $\mathrm{S}_{0}, \mathrm{~S}_{1}, \mathrm{~S}_{2}, \mathrm{~S}_{3}$ & $10,11,14,13$ & Select input \\
\hline
\end{tabular}

Fungsi dari konfigurasi pin IC 74HC4067 yang merupakan multiplekser dengan 16 kanal input ( $\mathrm{I}_{0}$ sampai $\mathrm{I}_{15}$ )yang diaktifkan oleh pemilih input kombinasi digital 4 pin ( $\mathrm{S}_{0}$ sampai $\mathrm{S}_{3}$ ), dan dengan memberikan Pin E tegangan rendah (Julsam, dkk, 2019). Kombinasi pin untuk mengaktifkan kanal-kanal pada multipleser seperti pada Tabel 2.

Tabel 2. Deskripsi Pin IC 74HC4067

\begin{tabular}{|c|c|c|c|c|c|}
\hline S0 & S1 & S2 & S3 & E & Selected Kanal \\
\hline$X$ & $X$ & $X$ & $X$ & 1 & None \\
\hline 0 & 0 & 0 & 0 & 0 & 0 \\
\hline 1 & 0 & 0 & 0 & 0 & 2 \\
\hline 0 & 1 & 0 & 0 & 0 & 3 \\
\hline 1 & 1 & 0 & 0 & 0 & 4 \\
\hline 0 & 0 & 1 & 0 & 0 & 5 \\
\hline 1 & 0 & 1 & 0 & 0 & 6 \\
\hline 0 & 1 & 1 & 0 & 0 & 7 \\
\hline 1 & 1 & 1 & 0 & 0 & 8 \\
\hline 0 & 0 & 0 & 1 & 0 & 9 \\
\hline 1 & 0 & 0 & 1 & 0 & 10 \\
\hline 0 & 1 & 0 & 1 & 0 & 11 \\
\hline 1 & 1 & 0 & 1 & 0 & 12 \\
\hline 0 & 0 & 1 & 1 & 0 & 13 \\
\hline 1 & 0 & 1 & 1 & 0 & 14 \\
\hline 0 & 1 & 1 & 1 & 0 & 15 \\
\hline 1 & 1 & 1 & 1 & 0 & \\
\hline
\end{tabular}




\section{b. PLC (Programmable Logic Controller)}

PLC (Programable Logic Controller) yang digunakan jenis OMRON dengan Series CP1L-E merupakan jenis PLC COMPACT yang memiliki 2 kanal analog input dengan rating kerja analog 0 sampai 10 Volt dengan resolusi analog sebesar 1/1000 (Omron, 2020). Kenaikan 10 mv menghasilkan perubahan 1 nilai ADC.

2 kanal analog pada PLC ini cocok untuk menjadi media simulasi pembuatan multiplekser analog pada PLC, dimana kanal analog 1 pada PLC dijadikan masukan multiplekser dan kanal 2 untuk pembanding data ADC inputan ke PLC secara langsung. PLC Omron dengan Series CP1L-E memiliki 12 pin Out digital yang lebih dari cukup untuk proses pensaklaran kombinasi bit ke multiplekser. Perancangan diagram rangkaian untuk multiplekser analog pada PLC OMRON CP1L diperlihatkan pada Gambar 6. Rangkaian multiplekser bekerja pada tegangan 5 vdc yang dihasilkan dari IC regulator 7805 yang bersumber dari tegangan 24 vdc dari PLC. Rangkaian Multiplekser ini memiliki 16 kanal input, yang dihasilkan dari 4 bit kombinasi (S0,S1,S2 dan S3), dan 1 Output(Y0).

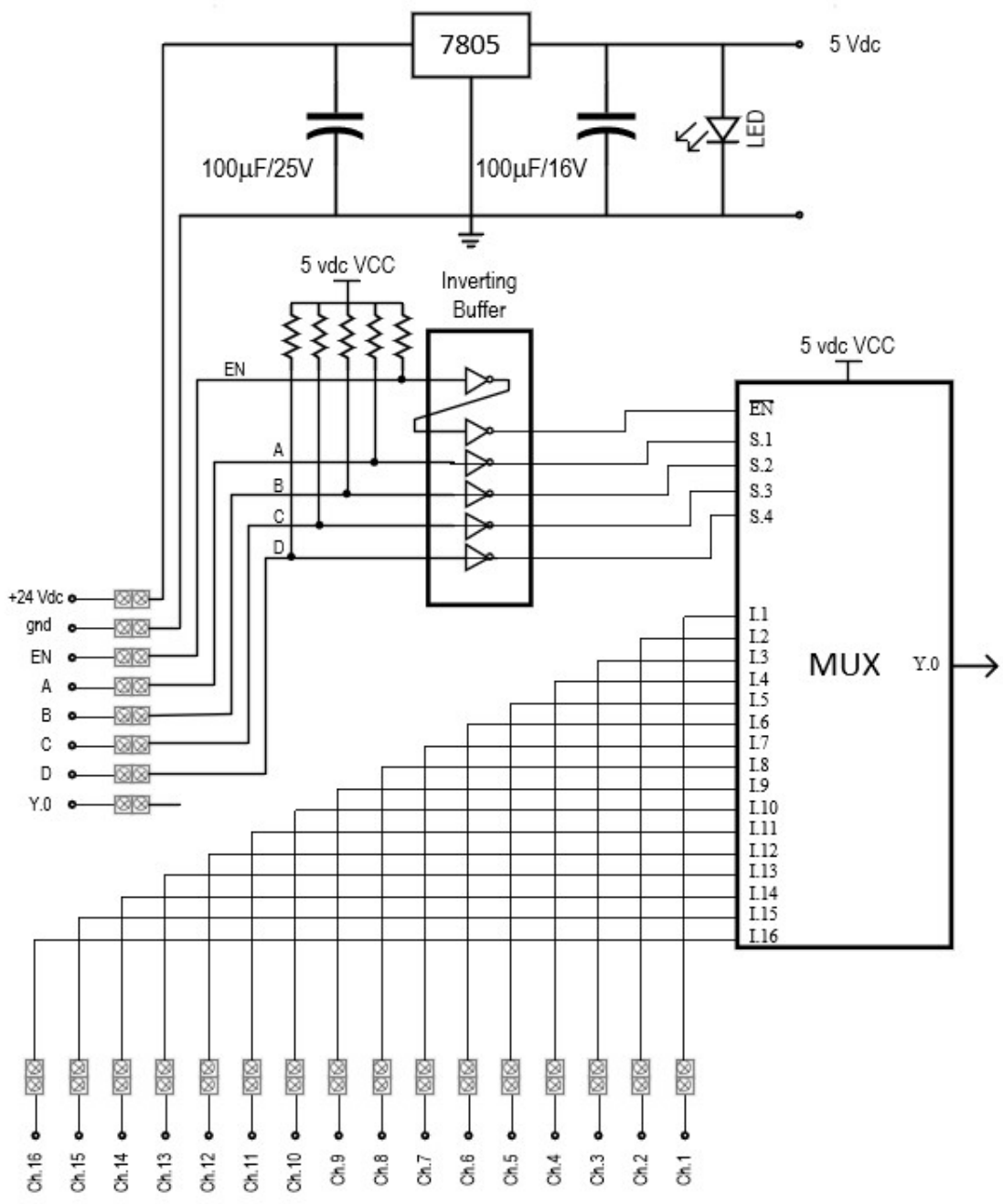

Gambar 6. Desain Skematik 
Selain kombinasi pensaklaran diatas $\left(S_{0}, S_{1}, S_{2}, S_{3}\right)$ mulltiplekser ini dilengkapi dengan 2 pin catu daya, 1 pin COM dan 1 pin enable untuk mengaktifkan dan menonaktifkan multiplekser secara terprogram seperti pada Gambar 7.

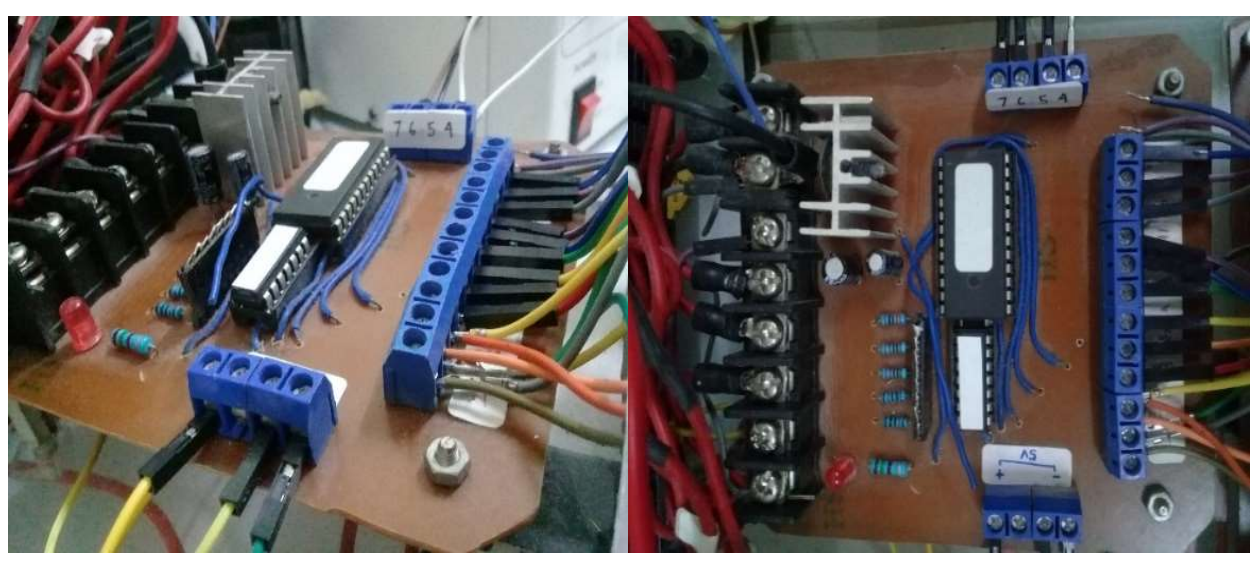

Gambar 7. Multiplekser Analog PLC

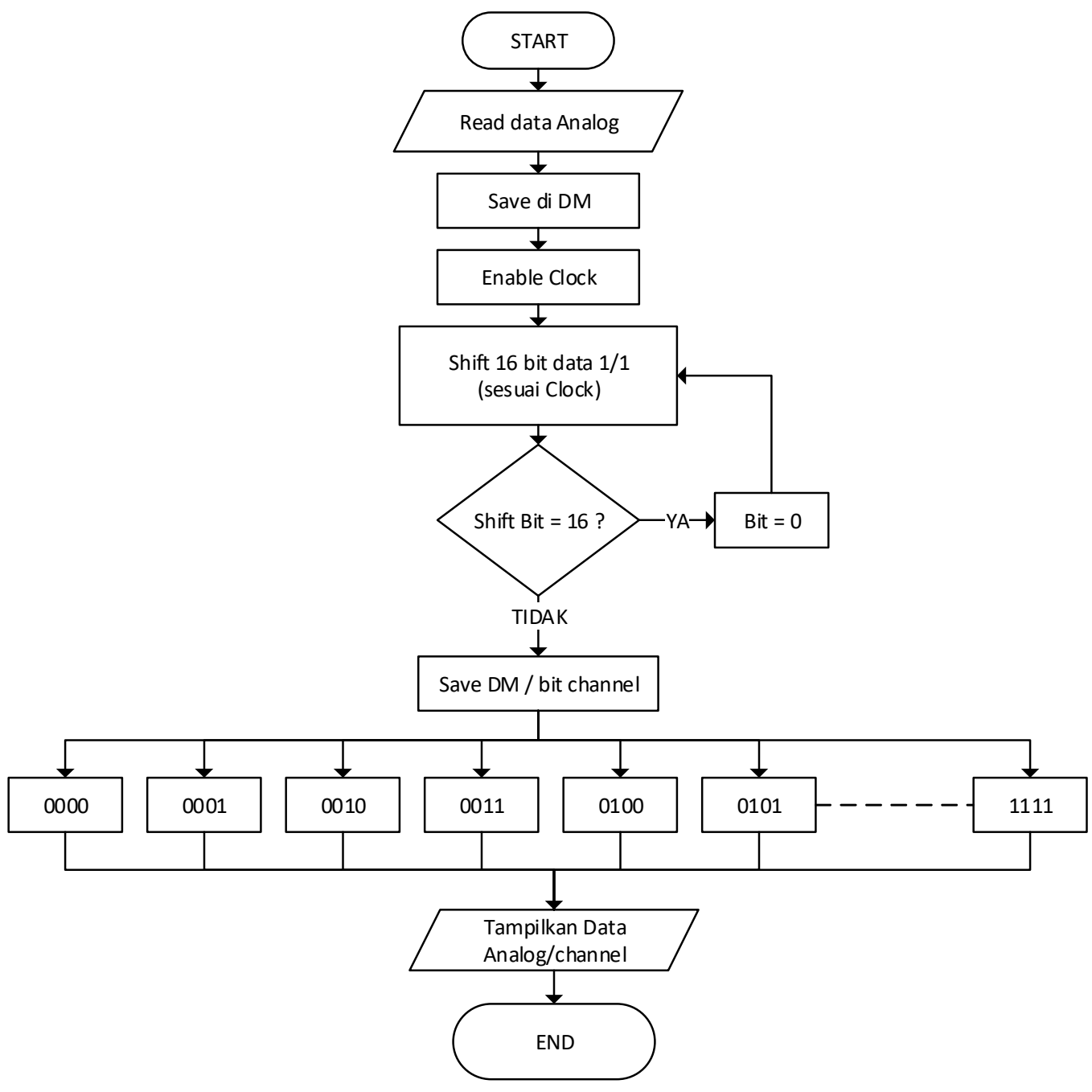

Gambar 8. Flowhart Demultiplekser Program PLC 


\subsection{Perancangan Software}

Perancangan Software dituangkan dalam bentuk flowchart demultiplekser yang diprogram menggunakan ladder diagram pada software CX-Programmer seperti pada Gambar 8. Proses pemisahan dan penyimpanan data analog berdasarkan kanal yang yang di berikan dari multiplekser melalui 1 kanal analog PLC diatur menggunakan shift register dengan kombinasi 4 bit, setiap pergeseran bit yang dihasilkan oleh shift register menyimpan data analog pada masing-masing penyimpanan di Data Memory PLC dan kemudian di tampilkan.

\section{HASIL DAN PEMBAHASAN}

Hasil dari pengujian untuk penelitian multiplekser analog pada PLC menggunakan IC74HC4067 ini diuji berdasarkan clock switching dan perbandingan data ADC. Teknis pengujian seperti pada Gambar 9, dimana perbandingan pembacaan data analog melalui multiplekser pada ch1 (Channel 1 ) PLC dibandingkan dengan data analog yang masuk ke ch2 (Channel 2 ) PLC tanpa melalui multiplekser. Pengujian dilakukan dengan memberikan tegangan yang sama besar pada kanal multiplekser dan tanpa multiplekser mulai 0 sampai 10 volt oleh regulator DC.

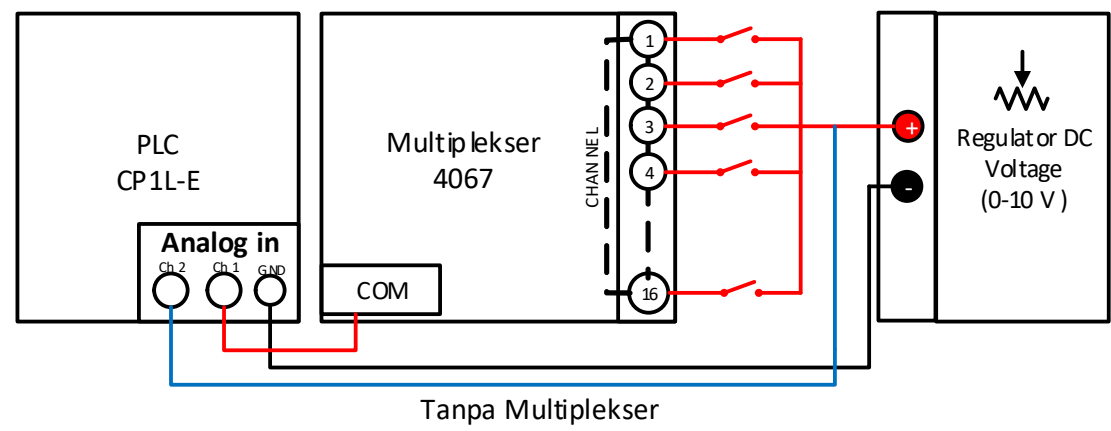

Gambar 9. Teknis Pengujian

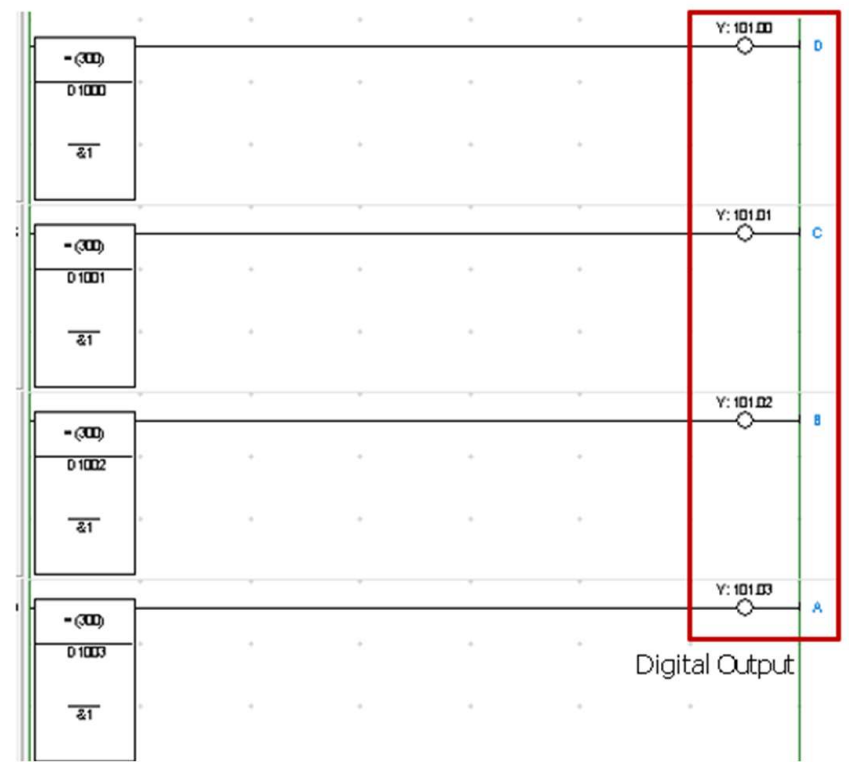

Gambar 10. Potongan Program PLC Switching Multiplekser 
Proses pengambilan data multiplekser oleh PLC dilakukan sesuai dengan program pada Gambar 10. Untuk mengaktifkan pengambilan data kanal 1 sampai 16 pada multiplekser dilakukan dengan pensaklaran 4 bit yang dilakukan oleh 4 kanal digital output PLC dimana konfigurasinya pensaklaran sesuai dengan Tabel 2. Proses pensaklaran 4 bit tersebut menggunakan fungsi shift register pada program PLC.

Kombinasi output digital yang dihasilkan oleh PLC juga menjadi sebuah inputan kombinasi untuk penyimpanan data memori di PLC seperti pada Gambar 11, dimana penempatan data analog kanal di atur oleh kombinasi 4 bit ( $A, B, C, \& D$ ) yang memindahkan hasil dari pembacaan input analog kanal 1 PLC disimpan di beberapa slot data memori mulai dari D301 sampai D316.

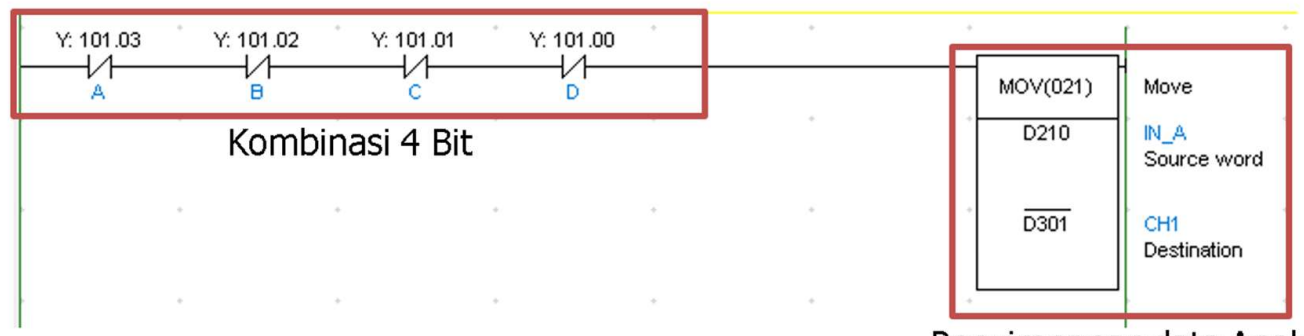

Penyimpanan data Analog

\section{Gambar 11. Potongan Program Demultiplekser di PLC}

Pengujian dilakukan dengan memberikan tegangan yang sama pada tiap kanal multiplekser dan variasi kecepatan pensaklaran mulai dari 0,1 detik sampai 0,6 detik dimana besar tegangan 0 sampai 10 volt.

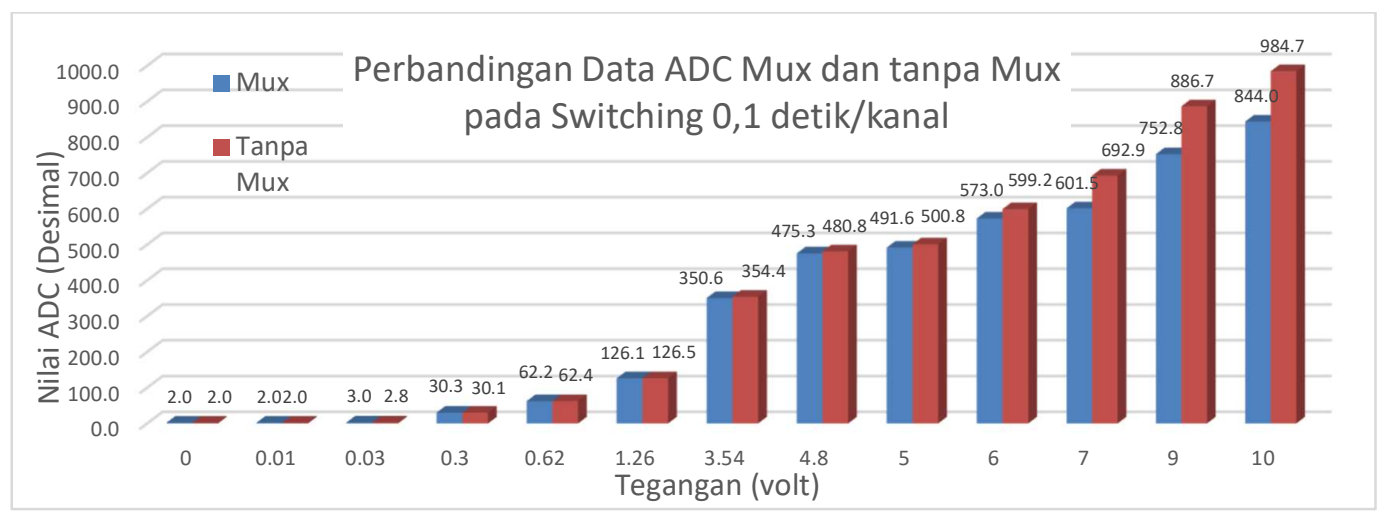

Gambar 12. Hasil Pengujian multiplekser dengan clock 0.1 detik

Hasil pengujian pada clock 0,1 detik/kanal sesuai dengan Gambar 12 memperlihatkan perbedaan signifikan mulai pada tegangan 3,54 volt antara yang menggunakan MUX dan tanpa MUX 


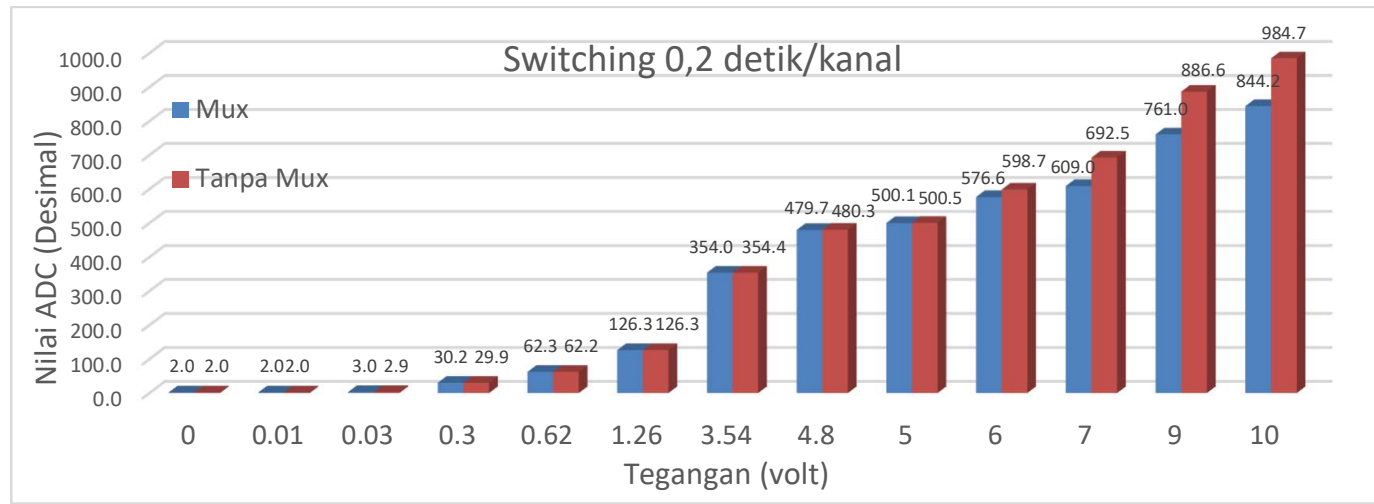

\section{Gambar 13. Hasil Pengujian Multiplekser dengan Clock 0.2 Detik}

Gambar 13 memperlihatkan hasil pengujian dengan switching 0.2 detik/kanal perbedaan yang terjadi sama dengan pada pengsaklaran 0,1 detik/kanal yaitu di 3,54 volt, meskipun tidak besar dan terjadi perbedaan signifkan pada tegangan 6 volt. Pada pengujian swiching 0,4 detik/kanal perbedaan besar terjadi pada tegangan 6 volt antara MUX dan tanpa MUX.

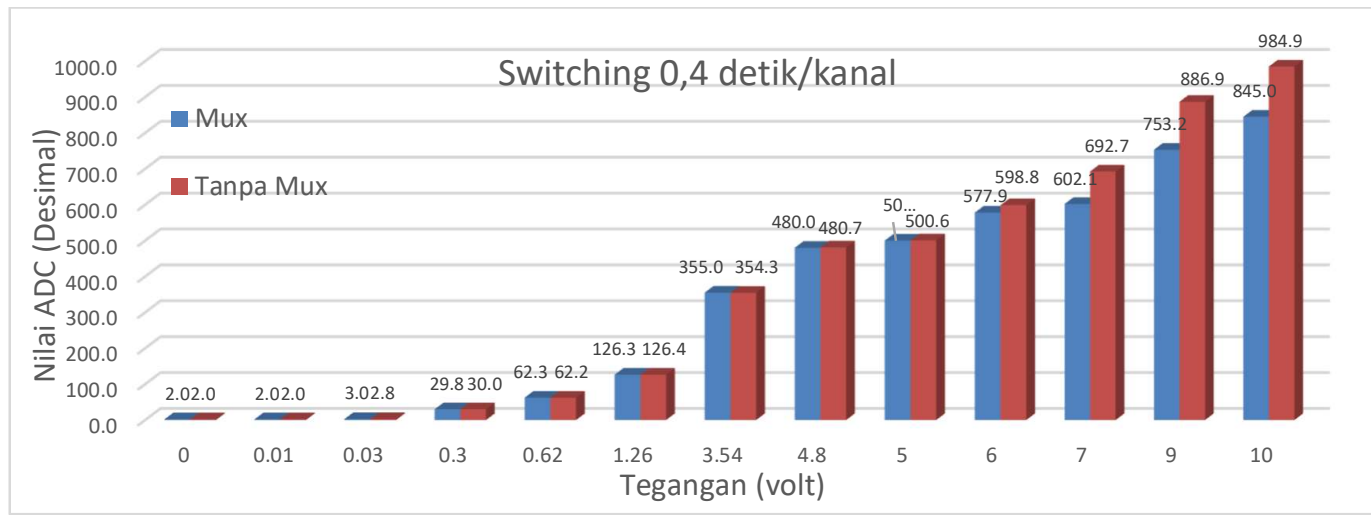

Gambar 14. Hasil Pengujian Multiplekser dengan Clock 0.4 Detik

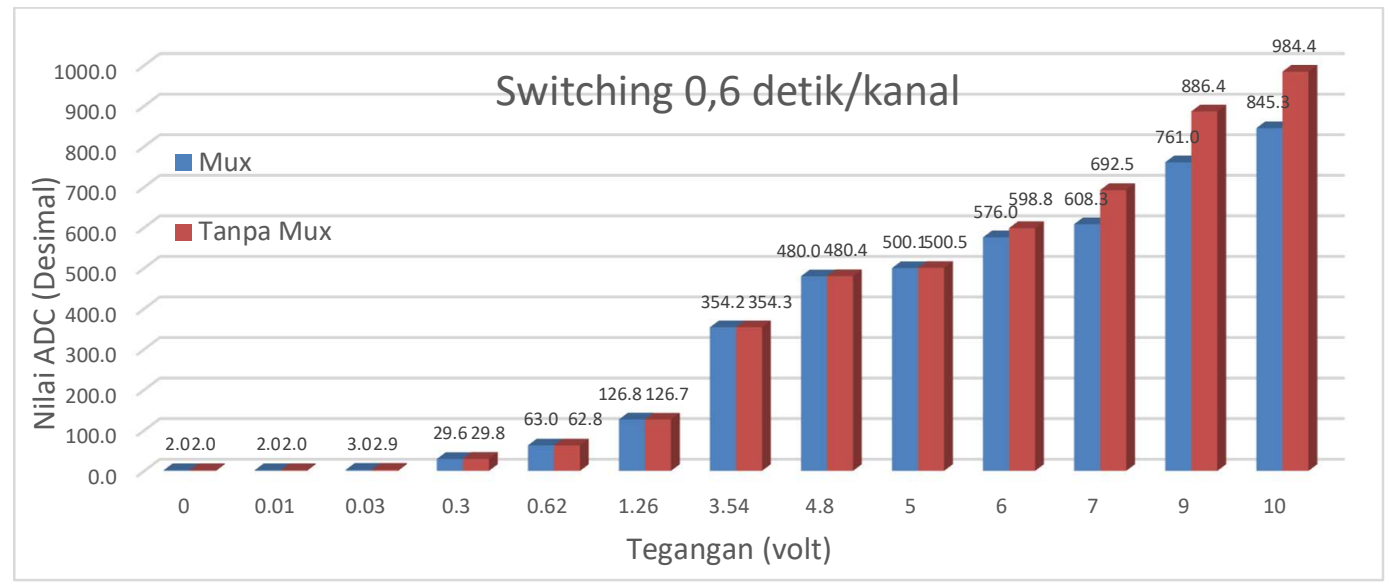

Gambar 15. Hasil Pengujian Multiplekser dengan Clock 0.6 Detik

Gambar 15 memperlihatkan pengujian di bawah 5 volt menghasilkan kesamaan tegangan ADC baik untuk MUX maupun tanpa MUX. 
Dari selisih pengujian yang ada, direkomendasikan input analog multiplekser antara 0 sampai 5 volt karena diatas tegangan 5 volt multiplekser mengalami error yang cukup besar. Hal ini disebabkan oleh tegangan kerja IC 74HC4067 sebesar 5 volt. Selisih nilai error dapat kita hitung dengan Persamaan (1):

$$
\% \text { error }=\frac{\sum M u x-\sum \text { Tanpa Mux }}{\sum \text { Tanpa Mux }} \times 100 \%
$$

diperoleh hasil error pada setiap kecepatan pensaklaran menurut Persamaan (1) pada Tabel 4.

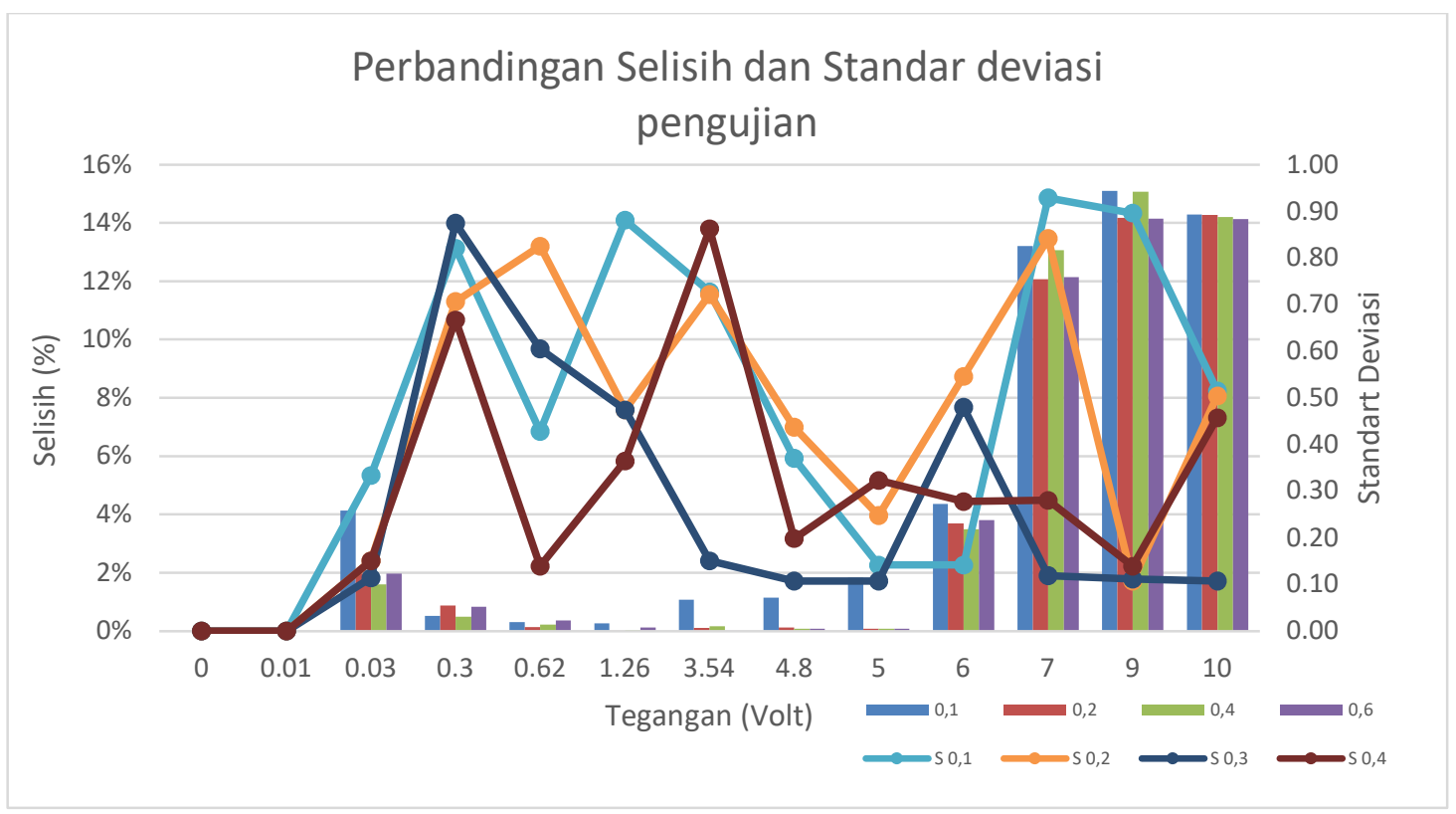

Gambar 16. Grafik Hasil Perhitungan Perbandingan Selisih dan Standar Deviasi

Berdasarkan Gambar 16, 0,1 merupakan pengujian multiplekser pada kecepatan switching 0,1 detik/kanal, 0,2 merupakan pengujian multiplekser pada kecepatan switching 0,2 detik/kanal dan seterusnya. Dari pengujian dapat dilihat bahwa multiplekser yang dibuat dapat bekerja secara optimal pada rentang tegangan 0,3 sampai 5 volt. Tegangan dibawah 0,3 volt rentang terhadap gangguan yang disebabkan oleh ketidaksetabilan catu daya dan multiplekser ini tidak dapat bekerja secara optimal diatas tegangan 5 volt karena melebihi tegangan kerja IC 74HC4067. Dari Gambar 16, juga dapat dilihat kecepatan switching 0,1 detik/kanal menghasilkan selisih paling besar dibandingkan dengan yang lainnya. Standar Deviasi pengujian diperlihatkan $S$ 0,1 untuk deviasi pengujian multiplekser pada kecepatan 0,1 detik/kanal, S 0,2 untuk deviasi pengujian multiplekser pada kecepatan 0,2 detik/kanal, dan seterusnya. Untuk menentukan kalkulasi total waktu 1 siklus pensaklaran multiplekser berdasarkan jumlah kanal menurut algoritma yang diprogram dapat dituangkan dalam persamaan matematis

$$
T P C=\text { Clock } \times \sum_{i=0}^{n} \mathrm{Ch}
$$


Dimana:

$\begin{array}{lll}\text { TPC } & : \text { Time per Cycle }(\mathrm{ms}) \\ \text { Clock } & : \text { Waktu switch / kanal (ms). } \\ \text { Ch } & : \text { kanal analog yang dinginkan (1 sampai } 16)\end{array}$

Perbandingan waktu pensaklaran pada multiplekser dengan tanpa multiplekser dimana kanal tanpa multiplekser bekerja secara kontinyu ( tanpa ada jeda), lain hal dengan pembacaan data analog yang melalui multipkser terdapat jeda waktu seperti pada Gambar 17.

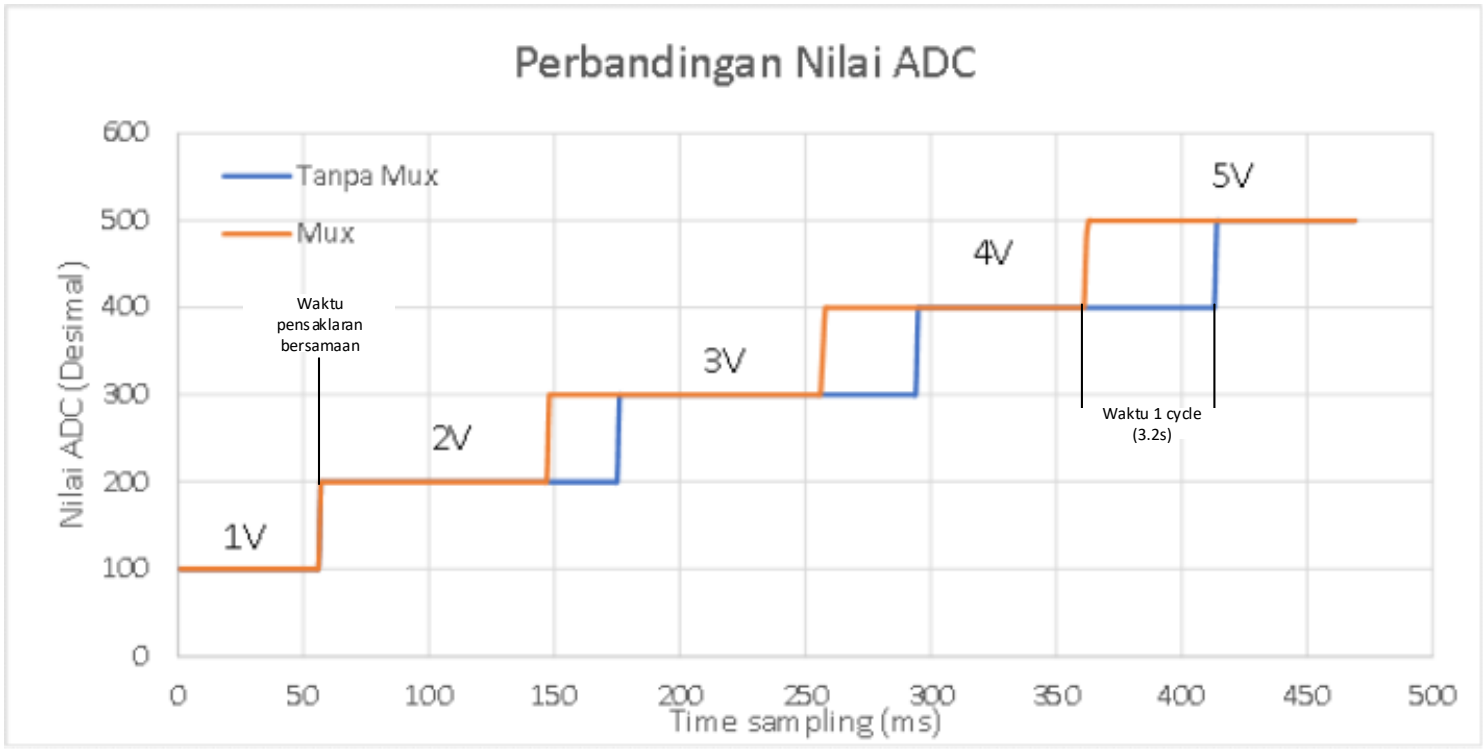

\section{Gambar 17. Akurasi Data Pembacaan Analog}

Jeda waktu terjadi akibat adanya sinyal pensaklaran 4 bit PLC ke multiplekser yang mengatur kanal multiplekser mana yang aktif. Bila waktu pensaklaran nya bersamaan dengan perubahan sinyal analog dari regulator DC maka sinyal multiplekser dan tanpa multiplekser akan saling berhimpit (bersamaan) dan apabila waktu pensaklaran tidak sesuai maka pembacaan yang melalui mux akan menunggu sampai kondisi proses pensaklaran terpenuhi

\section{KESIMPULAN}

Metode untuk memperbanyak akses input analog yang digunakan pada PLC ini dengan menggunakan konsep pensaklaran kanal dimana 1 kanal input analog pada PLC menjadi inputan 16 kanal analog dengan konsep multipleksing yang ada pada IC 74HC4067. Kemudian gabungan data yang masuk pada analog PLC tersebut di pisahkan lagi sesuai dengan kanal nya menggunakan metode demultiplekser yang terprogram pada PLC. Hasil pengujian proses pembacaan data analog melalui multiplekser bekerja dengan baik hanya pada tegangan 0 sampai 5 volt atau dapat dikatakan setengah dari resolusi PLC yang digunakan, namun multiplekser yang dibuat cocok dengan proses pembacaan data-data analog pada PLC dengan spesifikasi $0-5 \mathrm{v}$ atau data analog 4- $20 \mathrm{~mA}$. Waktu pensaklaran direkomendasikan diatas 0,1 detik per kanal berdasarkan hasil selisih pembacaan nilai ADC dibandingkan dengan tanpa melalui multiplekser berkisar antara 0,00\% sampai 1,969\%. Pemanfaatan multiplekser analog pada PLC dapat digunakan untuk menghemat biaya penambahan ekstensi tambahan analog pada PLC yang cukup mahal. 


\section{DAFTAR RUJUKAN}

Ahmad, A. (2012). Perkembangan Teknologi Komunikasi Dan Informasi. Dakwah Tabligh, 13, 137-149.

Anton, Anggraini, T., \& Ikhsan, M. (2015). Pengendalian Beban Generator Otomatis Berbasis PLC dan SCADA dengan Mempertimbangkan Arus pada Konsumen. 6th Industrial Research Workshop and National Seminar.

Gong, N.-W., Steimle, J., Olberding, S., Hodges, S., Gillian, N. E., Kawahara, Y., \& Paradiso, J. A. (2014). PrintSense. Proceedings of the SIGCHI Conference on Human Factors in Computing Systems, (pp. 1407-1410).

Hidayat, R. (2015). Analisis Pemanfaatan Multiplexer Analog 74HC4051 pada Mikrokontroller ATMega16. Isu Teknologi, 10(2).

Julsam, Sk, R., Kartika, \& Mulyadi. (2019). Penggunaan Modul Multiplexer CD74HC4067 Untuk Menambah Input Analog Pada NodeMCu ESP8266. 3(1), 363-367.

Mukherjee, K. (2020). Method of implementation and application of all-optical frequencyencoded multiplexer and demultiplexer utilizing total reflectional switches (TRSs). Journal of Optics (India), 49(1), 102-109.

Nugroho, T. W., Aliyu, A., \& Prasojo, J. (2017). Rancang Bangun Alat Pengirim Sinyal Arus 4 $20 \mathrm{~mA}$ dari Pemancar Suhu melalui Jaringan GPRS. ELKOMIKA, 5(1), 2459-9638.

Omron. (2020). CP series CP1L CPU Unit D -D / CP1L-EL D -D High Performing Programmable Controller with Embedded Ethernet.

Petruzella, F. D. (2017). Programmable Logic Controllers (5th ed.). New York: McGraw-Hill Education.

Rachmat, H. H., Akbar, W. A., Suhendar, E., \& Fariz, M. I. (2016). Pengembangan Skala Pengukuran Massa Timbangan Digital Kamar Mandi dengan ADC 24 bit berbasis Kontroller Arduino. Seminar Nasional Desain \& Rekayasa Itenas 2016, (pp. 120-123).

Rangarajan, S., Kidane, A., Qian, G., \& Rajko, S. (2008). Design Optimization of Pressure Sensing Floor for Multimodal Human-Computer Interaction. In Human Computer Interaction.

Rizaldi, I., Murti, M. A., \& Susanto, E. (2015). Perancangan Sistem Kendali Boiler Menggunakan Algoritma Pid Pada PIc ( Programmable Logic Controller) Omron Design Control System Boiler Using Pid Algorithm on Plc ( Programmable Logic Controller ) Omron. EProceeding of Engineering,(pp. 1949-1956).

Sagita, S. M., Khotijah, S., \& Amalia, R. (2013). Pengkonversian Data Analog Menjadi Data Digital Dan Data Digital Menjadi Data Analog Menggunakan Interface Ppi 8255 Dengan 
Bahasa Pemrograman Borland Delphi 5 . 0. 6(2), 168-179.

Sarjana. (2019). Modul Converter (Adc Dan Dac) Dengan Seven Segment Display. Jurnal Informanika, 5(1), 27.

Weber, P., Rueckert, E., Calandra, R., Peters, J., \& Beckerle, P. (2016). A low-cost sensor glove with vibrotactile feedback and multiple finger joint and hand motion sensing for humanrobot interaction. 2016 25th IEEE International Symposium on Robot and Human Interactive Communication (RO-MAN), (pp. 99-104).

Wisitwekin, A., Pongmala, C., Suputtitada, A., \& Somboon, P. (2017). Development of gait training system with realtime auditory biofeedback for telerehabilitation. 2017 International Electrical Engineering Congress (IEECON), (pp. 1-4).

You, Z., Zahid, A., Heidari, H., Imran, M., \& Abbasi, Q. H. (2018). A Compact Wearable System for Detection of Plantar Pressure for Diabetic Foot Prevention. 2018 IEEE Asia Pacific Conference on Postgraduate Research in Microelectronics and Electronics (PrimeAsia), 2018-Octob(September 2018), (pp. 64-67). 